\title{
DE
}

DE GRUYTER

OPEN

\section{English language pre-service and in-service teachers' self- efficacy and attitudes towards integration of students with learning difficulties}

\author{
Ivana Cimermanová \\ University of Presov, Slovakia \\ ivana.cimermanova@unipo.sk
}

\begin{abstract}
The study of foreign languages is obligatory for all pupils in Slovakia, where the first foreign language is English. Conforming to integration legislation, pupils with special educational needs (SEN) are taught in mainstream classes. Foreign language teachers, however, lack training and where not prepared how to apply teaching methods and techniques for pupils with SEN in the regular language learning class. In the study presented, 187 elementary school teachers filled out questionnaires dealing with integration of pupils with SEN and possible inclusion of learners with disabilities in Slovakia and a group of 56 university FLT students - teachers-to-be. Teachers are not forced and/or encouraged to take part in in-service courses or other education on how to teach these pupils. The pre-service teachers are offered courses on SEN teaching, however, these are not compulsory and mostly general education oriented. The majority of in-service and preservice teachers felt that pupils with SEN should be taught in regular education class. The article also describes the current situation concerning integration of students with SEN using the official statistical data.
\end{abstract}

\section{Keywords}

SEN, pre-service teacher, in-service teacher, integration, mainstream class, special education needs

\section{Introduction}

Foreign language learning in Slovakia is an integral and compulsory part of educational system. Currently, it is only English language that is taught as an obligatory subject (concerning foreign language learning) and it is taught since the third grade of the elementary school. In addition, many schools introduce it as a mandatory course since the first grade. The author brings information (including the statistical data) about integration of learners with SLD, discusses possible exemptions from learning foreign languages (and gives evidence how it is applied in Slovak schools). The article also brings data collected in a group of elementary 
school teachers on their knowledge how to treat students with SLD in foreign language classes and their needs and pre-service teachers about their attitudes towards integration. Students with dyslexia who are integrated in the intact classes tend to face some difficulties in foreign language learning (FLL) and FLL teachers have to be prepared to give appropriate attention to all students in a classroom. Previously, we have worked with two groups separately (in-service and pre-service teachers, however some aspects of those researches were interrelated and we decided to present some aspects in comparison.

\section{SEN and Slovak legislation}

Academic Network of European Disability experts published in 2010 country reports on equality of educational and training opportunities for young disabled people. The information includes also data on learners with special education needs in Slovakia and their education.

The Code of Practice on education and upbringing of learners with special education needs at elementary and secondary schools no. CD - 2004-12003/235971:095 was approved by the Ministry of education of the Slovak Republic on August 31, 2004 and valid since September 2, 2004. The document discusses organisation of education of learners with SEN, individual plans and also evaluation of learners with special educational needs at elementary and secondary schools.

According to the strategic document The Key areas and actions plans of state policy focused on children and youth in the Slovak Republic for years 2008-2013 "the state is obliged to create conditions for improvement education of children and youth with special educational needs" $(2008$, p. 3$)$. The National action plan for children for years 2008-2012 states that: "Education, leisure time and culture activities", point 3.3 commits the Ministry of Education of the Slovak Republic "to better availability of instruments for support of accessibility to education for all children, including children with disabilities and children from minorities corresponding to approved governmental departments' conceptions". Brychtova, Hanzelova and Repkova (2007) claim that "Despite the priority to ensure education for children and young persons with disabilities in mainstream/inclusive school and learning settings, current practice administers the education of this target group as two institutionalised tracks ( $\$ 94$ of the School act):

1. education in mainstream schools

- as individualised integration - individual pupil attends ordinary school in ordinary class; or

- as "semi-integration" in special classes placed within ordinary schools

2. education in special schools. 
Regardless of the form of the educational model (track), special disability support provisions are only put in place if a child/pupil gains a special status. According to the Act No. 245/2008 Coll. on Education (School Act) the status is based on recognition of a child's or pupil's special educational needs, which means that a child or pupil requires in education a special accommodation of conditions, content, forms, methods and approaches due to his/her "health handicap". A child's or pupil's special educational needs are assessed by a special authority the facility for educational counselling and prevention. According to $\S 144$ of the School act "a child/pupil with special educational needs has a right for education by utilising of some specific forms and methods corresponding to his/her needs and for creating of necessary conditions which are needy for the education... he/she has right to utilise by education special textbooks and special didactic and compensation aids". Pokrivčáková (2015, p. 21) summarises that even though "the legislation and state documents related to education are in accord with international standards, and thus create standard conditions for the development of foreign language education of the target group", on the other hand "the existing situation at schools is not very optimistic". She also mentions a necessity to integrate information on teaching SEN in pre-service teacher training programmes as well as lack of teaching material and practical handbooks, etc..

It is necessary here to clarify exactly what is meant by integration and inclusion as those two terms are sometimes used interchangeably. Jones $(2004$, p. 12) describes and compares both terms. According to her, the term integration is generally understood to mean "bringing children from special into mainstream settings, and are concerned with the placement of individual children rather than the narrowing of social and educational gaps between them". As the main differences between integration and inclusion she highlights the focus in the needs of individual with disability (while in the inclusion the focus is placed on the needs of all students). In the integration the expertise of specialists, special programs for a students with disabilities and evaluation of students is done by experts while in inclusion we deal with expertise of current teachers, focus on school and its change, active participation and collaboration, strategy of a teacher and teacher's assessment.

The official methodology guidelines for teaching foreign language to learners with learning difficulties enumerate the following:

- be reinforcing

- respect individual tempo and mode of learners' work

- apply multisensory approach: to look for and connect images and words and vice-versa

- to connect communication with the physical activity

- new structures immediately use in communication (especially grammar ones) 
- new vocabulary taught in phrases

- to prefer oral form of language and its testing

- be careful in error correction; the main criterion should be comprehensibility rather than accuracy, the use of computer is suggested and recommended for individual work and home preparation

- use the same font/type of letters

- do not use the columns but lines for texts

- do not use text in so called "bubbles" or "callouts"

- structured handouts with easy orientation, no distracting elements

- set the real aims - progress in steps

- the verbatim translations are not recommended

- read the words as whole units/ whole shapes - so called global method

- use audio-recordings to train the correct pronunciation.

As to the evaluation and assessment it is important to realise that one deals with learner with developmental learning problems, but it is also accompanied with the lack of communication, verbal, non-verbal and social strategies. This is one of the reasons why the evaluation should be done individually:

- do not asses learner in the context of the whole classroom; it is suggested to rather evaluate learner's progress, his/her own progress and effort

- evaluate learner continuously

- evaluate his/her work as soon as possible after their work

- prefer oral examination - based on the supporting questions; prepared guidelines, structures

- limit examination in front of the board / in front of the whole class

- do not evaluate the quality of written letters

- it is not necessary to classify every written work

- focus on contents rather than form, presentation

- vary different types of assessment - grades, verbal evaluation, points, symbols

- in case of (numerical - grade, points) classification add also the verbal, information to evaluate also the progress and conditions - formal evaluation can lead to formal performance

- use also the social rewards in evaluation, social recognition - attention, applause, hug

- „self-evaluation" can have a significant influence on the learner's performance 
Sabo and Pavlíková (2011, p. 12) schematically present the model of integration (see figure 1 below).

\section{MODEL OF INTEGRATION}

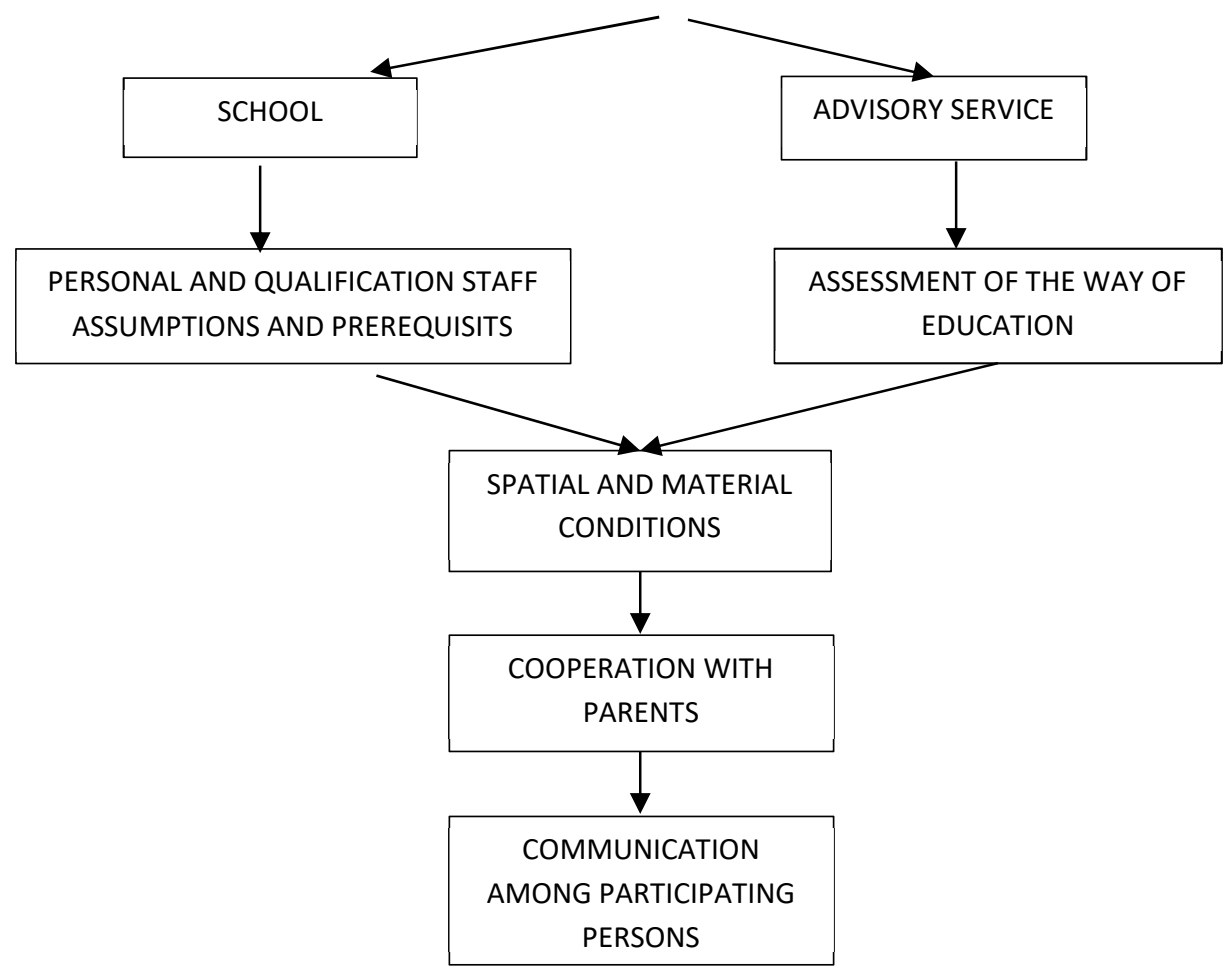

Figure 1: Model of integration

Schools create and provide special educational programs which are specialised according to the type of disability. In case that it is necessary to accommodate the content and forms of education the teacher in cooperation with the special pedagogue create the modification of the particular course contents. Concerning foreign language learning; the quality of the input plays a vital role, as it is the information that enters the learner's brain which is further processed (Eddy, 2011). It is also important that teachers make their decisions with the main outcome in mind - the learner should reach the elementary communication skills, to use basic phrases, idioms, questions, etc.. 
As it can be seen from the figure 1 the communication and cooperation of teachers, specialist and parent is important for successful integration. Similarly, preparation of environment and materials is important. Teachers and their mastery is play a crucial role in not only integration process but helping learners to overcome learning barriers, using appropriate learning and compensation strategies, etc. To work with learners with disabilities (in the mainstream classes) it is very important not only to be aware of what and how to teach but also to realise the principles of brain based learning (Sepešiová, 2013). With the number of integrated learner and the teachers admitting teaching integrated learners (see data below) it is, as Pokrivčáková stated above, a must to reflect the situation in teacher training curricula programmes (the information on status quo is below).

\section{Review of literature}

The examination of the literature on foreign language learning by learners with disabilities reveals there is a large volume of published studies bringing information on the benefits of language learning, the practices and policies of language exemption, the perceptions of students and teachers regarding those practices.

Integration and inclusion places (should place) demands not only on in-service teachers but also on pre-service teacher preparation. The impact of inclusion and integration has been the subject of numerous studies (Ruijs, Peetsam, 2009; WongRatcliff, M., \& Kwok Keung, H., 2011; Salend, Duhaney, 1999; Andreson, S.L., Gumus, S.S., 2006).

Several studies have reported the concerns and attitudes of pre-service teachers and teachers to inclusion of pupils with special education needs. To study the attitudes of teachers or pre-service teachers towards inclusion of the students the SACIE scale was developed. The original combination of 60 items from three different scales resulted in 19 item scale The Sentiments, Attitudes, and Concerns about Inclusive Education (see Loreman et al, 2007). This was later revised and modifications resulted in SACIE-R (The Sentiments, Attitudes, and Concerns about Inclusive Education - revised) -15 items survey using 4point scale (strongly agree to strongly disagree) (see Forlin, et al., 2011). This will be used as a part of research in the next stage of the researches mentioned above.

Interesting results are also reported about the relation between self-efficacy and attitude towards inclusion (see e.g. Sharma, Shaukat, and Furlonger, 2015; Hofman, Kilimo, 2014). Numerous studies reported the positive effects of courses on inclusion and teaching children with SEN and some of them also described the content of those courses (e.g. O'Gorman \& Drudy, 2011; Malak, 2013; Oswald \& Swart, 2011; Ahsan, Sharma \& Deppeler, 2012). 
Sparks (2009, p. 16) pointed out that "the most important issue masked by the use of course substitutions and waivers is that special educators and foreign language instructors feel no sense of urgency to develop teaching methods that can be used with at-risk learners”. Wight (2015, p. 40) adds that „rather than accepting exclusionary practices, educators, administrators, counsellors, learners, and other stakeholders should focus instead on developing and promoting inclusive foreign language learning environments".

There is a large and growing body of literature that has investigated the status of integration/inclusion in different countries (e.g. Nash \& Norwich, 2010; Rodriguez \& Garro-Gil, 2014; Bendová \& Fialová in Czech Republic; O'Gorman et al., 2011 in Ireland; Russak, 2016 in Israel; Ghergut, 2010 in Romania; Ahsan, Sharma, \& Deppeler, 2012 in Bangladesh; Malak, 2013 in Bangladesh; Meek, 1996 in Great Britain; Sharma, 2012 in Australia; Valeeva, 2012 in Russia; Miškolci, 2016 in Slovakia, etc.).

In some countries schools recorded that "parents of children in mainstream schools express concern about the negative effects of diversity in their children's class and express fears that this diversity will negatively affect the academic achievement of their children. As a result, many parents place their children in private schools" (Aigner, 2013, in: Braunsteiner \& Mariano-Lapidus, 2014, p. 36) (compare the results in Slovakia - table 1).

In Slovakia, primary level pre-service teacher education has been revised and reflects the integration of the pupils with SEN. The course on SEN are the part of curricula at most universities. This is, however, not the truth about the secondary level teacher training programmes. Another factor that might significantly impact the attitude of pre-service teacher is the fact that "Faculty staff who have not been significantly engaged in classrooms for more than ten years may believe that they are poorly placed to prepare teachers for the changed dynamics of teaching involved in an inclusive philosophy in the new century. In some instances inherited conservative assumptions and lack of personal participation in transformative learning experiences may be at odds with an inclusive way of thinking" (Forlin, 2010, p. 249).

\section{Background of the research}

It is becoming increasingly difficult to ignore the initial teacher education regards integration SEN pupils in Slovakia. From the following data (based on national statistics) it is apparent that there is a significant number of integrated learners to the mainstream classes what naturally places demands on more teachers. It has been mentioned above, that many parents place their children in private schools. In Slovakia the numbers of integrated learners is comparable in all three types of schools - state, private and church school. However, if we 
compare ratio of integrated learners specifically in grammar school, the number is relatively higher (doubled) compared to state and church schools (see table 1 below). The gender imbalance can be noticed in the results as well. The number of male integration is more than twice higher compared to female integration (here the data also should be perceived with respect to the number of diagnosed learners, what was not a scope of our research).

Table 1: Number of integrated students (in per cents) exempt from studying foreign language (Source of data CVTI statistics)

\begin{tabular}{|l|c|c|c|c|c|c|c|c|c|c|c|c|c|}
\hline \multicolumn{10}{|c|}{ Ratio of integrated learners with SLD to total number of pupils/learners (in \%) } \\
\hline & \multicolumn{3}{|c|}{$\begin{array}{c}\text { state schools - } \\
\text { integrated SLD }\end{array}$} & \multicolumn{3}{c|}{$\begin{array}{c}\text { private schools - } \\
\text { integrated SLD }\end{array}$} & \multicolumn{2}{c|}{$\begin{array}{c}\text { church schools - } \\
\text { integrated SLD }\end{array}$} & \multicolumn{4}{c|}{$\begin{array}{c}\text { TOTAL } \\
\text { integrated SLD }\end{array}$} \\
\hline & total & male & female & Total & male & female & total & male & female & total & male & female \\
\hline elem. s. & 3.11 & 4.13 & 2.04 & 2.78 & 3.18 & 2.32 & 3.49 & 5.02 & 2.20 & 3.13 & 4.16 & 2.06 \\
\hline gram. s. & 1.05 & 1.78 & 0.51 & 2.30 & 1.59 & 1.18 & 0.90 & 1.52 & 0.49 & 1.09 & 1.72 & 0.54 \\
\hline sec. s. & 4.16 & 5.44 & 2.48 & 3.92 & 5.04 & 3.00 & 3.05 & 5.18 & 1.99 & 4.10 & 5.40 & 2.52 \\
\hline Total & 2.77 & & & 3.0 & & & 2.48 & & & 2.77 & 3.76 & 1.70 \\
\hline
\end{tabular}

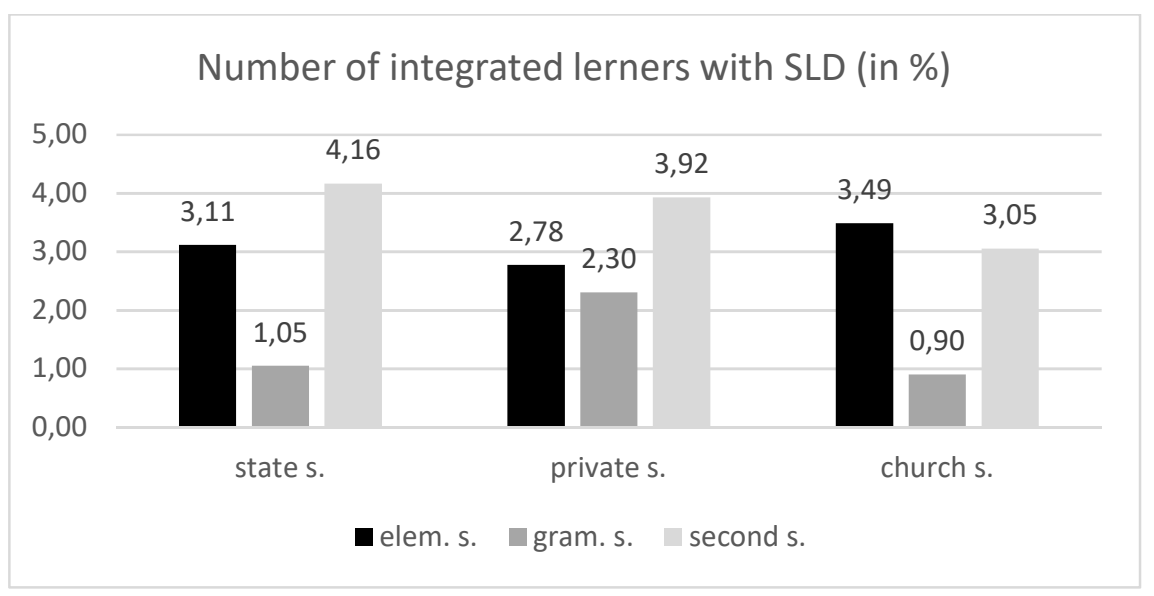

Graph 2: Integrated students (in per cents) exempt from studying foreign language (Source of data CVTI statistics) 
In majority of classes there are students with learning difficulties on different levels and there are also students that are not diagnosed. There is only a very low number of students that do not study foreign language (see the table below).

Table 2: Number of students (in per cents) exempt from studying foreign language (Source of data CVTI statistics)

\begin{tabular}{|l|c|c|c|}
\cline { 2 - 4 } \multicolumn{1}{c|}{} & \multicolumn{3}{c|}{ no language studied } \\
\multicolumn{1}{c|}{} & \multicolumn{1}{c|}{ \% out of the total no. of students) } \\
\cline { 2 - 4 } \multicolumn{1}{c|}{} & state & private & church \\
\hline elementary school & 0.15 & 2.63 & 3.46 \\
\hline grammar school & 0.54 & 0.00 & 0.08 \\
\hline secondary school & 2.94 & 2.99 & 5.50 \\
\hline
\end{tabular}

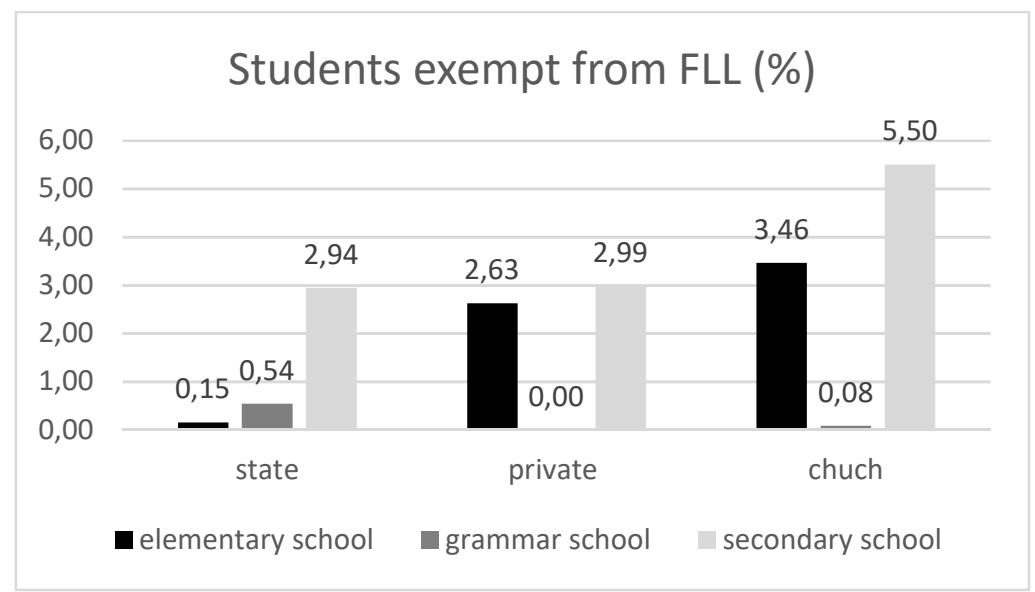

Graph 2 Students (in per cents) exempt from studying foreign language (Source of data CVTI statistics)

The problem of dyslexia is in fact associated with native language learning. There are various studies confirming that performance on standard measures of native language skill is related to the level of foreign language proficiency and indicate that students with SEN in their native tongue experience same problems in foreign language. 
To decide which language to offer an SLD learner we consider a type of difficulty and the foreign language itself. Each language has its problematic areas. Considering English language it has to be considered that it is an opaque language, it does not have letter-sound correspondence, and there are a lot of irregularities. German language has e.g. difficult compounds, articles, its tense system; Russian language uses different graphic system and orthography even though phonologically it is similar to Slovak language. The specialists suggest to consider the type of dyslexia (Kohútiková \& Viktorínová, 2009):

Dyslexia P - type - children with this type of dyslexia prematurely rely on right-hemispheric reading strategies. Learners read based on the perceptionspatial strategies, they stop at the phase of initial readers; i.e. they read quite accurately but their reading can be characterised as fragmented, (they read letters and syllables). They have problems to transfer the information to the left hemisphere. German language is suggested for learners with L-type.

Dyslexia L - type- children with this type of dyslexia prematurely rely on lefthemispheric reading strategies. Learners read mainly based on understanding the text, what has the signs of global method, global reading (read differently, written differently) - this method is used by more advanced learners. Reading is faster (hurried reading) but learners make more mistakes and guesses. English language is suggested for learners with L-type.

In Slovakia, as it has been mentioned the first foreign language for all pupils since the third grade at the elementary schools is English language (with no possibility of choice). Later, students can decide about their second foreign language (according to the possibilities of schools).

Back to the teacher preparation, teacher training study programmes are taught at 11 Slovak universities (out of 35 existing in total), foreign language teacher training at 10 universities, EFL teacher training at 8 universities. None of those 8 universities teaches SEN methodology as a compulsory subject in the English language part (teacher training programmes are usually studied as a combination of 2 major programmes with a compulsory pedagogy-psychology component), even though at some institutes teaching learners with SEN is one of the topics discussed in the EFL methodology course.

\section{Aims and methodology}

One of the major objectives of this study was to investigate the attitude of the pre-service and in-service teachers towards integration and inclusion in education and the readiness of pre-service English language teachers to teach learners with specific education needs who are integrated into regular classes. The research examined: 
- in-service teachers' attitudes towards inclusion and integration of students with specific learning needs

- pre-service teachers' attitudes towards inclusion and integration of students with specific learning needs

- pre-service teachers' awareness of the needs of SEN learners

\section{Instruments}

The survey was conducted using a modified version of the revised Sentiments, Attitudes and Concerns about Inclusive Education (SACIE-R) Scale (Forlin, Earle, Loreman, \& Sharma, 2011), a scale employing a 4-point Likert measure to elicit subject responses ranging from 1 (strongly disagree) to 4 (strongly agree). We used 10 point scale. Original SACIE-R consists of 15 items focussing on three areas (sentiments 7 questions, attitudes 2 question and 6 items concerns). For the purpose of the study additional questions were asked to learn more about their motivation for further study.

The European Portfolio for Student Teachers of Languages (EPOSTL) is a tool for reflection and self-assessment of the didactic knowledge and skills necessary to teach languages. The document is used by all English language major students at the University of Presov where the study was conducted. EPOSTL contains of 193 descriptors grouped into 7 categories (Context, Methodology, Resources, Lesson Planning, Conducting a lesson, Independent learning, and assessment of learning) that are further subdivided.

\section{Participants}

The research sample consisted of two groups; in-service teachers and preservice English Language teachers.

The survey was conducted among 187 teachers of the elementary schools teaching English language. Of the cohort 95.2\% were female while 4.8\% male working in three different districts (Prešov district, 41.2\%; Košice district, 31.6\%; and Banská Bystrica district 27.2\%). Concerning their teaching experience, it varied: $1.6 \%$ of them had up to 5 years of service; $43.3 \%, 6-15$ years; $5.3 \%, 16-25$ years; $33.7 \%$, 26-35 and $16.1 \%$, more than 36 years. A significant percentage of the sample were fully qualified elementary school teachers (K1-4); out of which slightly more than $2 \%$ had also a degree from English language teaching. There were 2 unqualified teachers in the sample.

The second group of sample consisted of 56 undergraduate students of both genders enrolled in a teacher teaching magister training programme (all students graduated the bachelor teacher training programme with single or double major English language and literature orientation and passed final state exam from the pedagogy and teacher psychology). The current study was realised following a 
semester of EFL methodology (39-unit of study distributed over a period of 13 weeks) and a 2-week teaching practice placement completed in a primary school.

\section{Procedure}

The in-service teachers to take part in a survey during the life-long learning courses. They were asked to fill in the questionnaire that was published online. The questionnaires were sent electronically to one of two course teachers.

The pre-service teachers work with EPOSTL as part of their EFL methodology course and they fill it in 4 times during their study; before teaching practice, after the first teaching practice ( 2 weeks placement at a primary school during the $2^{\text {nd }}$ semester of their study), after the second teaching practice ( 2 weeks placement at a secondary school during the $3^{\text {rd }}$ semester of their study), and after the third teaching practice ( 6 weeks placement at a primary and secondary school during $4^{\text {th }}$ semester of their study).

The pre-service teachers filled in the inclusion questionnaire during their lecture after the first teaching practise.

\section{Results}

The high number of teachers with no education in special education was expected. There were teachers (34.9\%) in the sample admitting they had no special training in teaching SEN learners. More than $15 \%$ studied special pedagogy, $9 \%$ of teachers passed the course (more than 60 hours) on teaching learners with SEN, 6\% passed 30-60 hours training; $29 \%$ took part in workshops or seminars that were shorter than 30 lessons.

Even though majority of them (58.6) indicated not to have integrated learners in their mainstream classes there is still a high number of teachers (41.4\%) who work with those students in their classes (including foreign language teaching). Here it is important to say that more than $45 \%$ of teachers in the sample believe there are SEN students in their classes who are not diagnosed. We have to admit that we deal only with the beliefs of the teachers and I would like to add that as many as $67 \%$ of teachers believe they can recognise learners with SEN and the same number of teachers feel they know how to work with those leaners (compare the data about qualification).

77 respondents systematically and intentionally read literature about SEN and on the other hand, there are $15 \%$ (28) of respondents who do not feel the need to read literature with the SEN theme. We were interested in who those respondents were and found out that 21 of them had not encountered diagnosed SEN learners; 17 out of them have not taken part in any training on subject matter; however 14 out of them believe they can identify learners with SEN (8 out of those 14 have no training in SEN teaching, and had no participated in any workshop oriented on SEN). Positive information we gained about the materials prepared for learners 
with learning difficulties. 55 teachers adapt the materials for learners with learning difficulties.

Confirming expectations the results show that almost every second teacher teaches learners with SEN, however, contrary to expectations, this study did not prove that majority of teachers feel the need to systematically study more about teaching SEN learners. They are generally quite confident in their abilities to diagnose and solve the issues with integrated learners. Still, even though they contended they do recognize the needs of these learners in EFL they face some problems connected with the number of learners in the class and integration of learners with different problems what results in much higher demands on planning, preparation and managing the mainstream class.

Pre-service teachers (in our research) expressed positive attitudes towards integration of pupils with learning difficulties and even though their self efficacy is relatively high (based on the data gained from their EPOSTL; average 55.87 but median is 60 what shows indicates there ae some outliers influencing the average), they are deeply and seriously concerned that their knowledge, skills and abilities are not sufficient to teach students with disabilities.

As an example we may present their answers (scale 1-10 with 10 being most positive) to the question I am confident that I can adopt teaching strategies to meet the needs of SEN students with an average value of 2.44 and standard deviation 1.47, minimal value 1 and maximum 6.

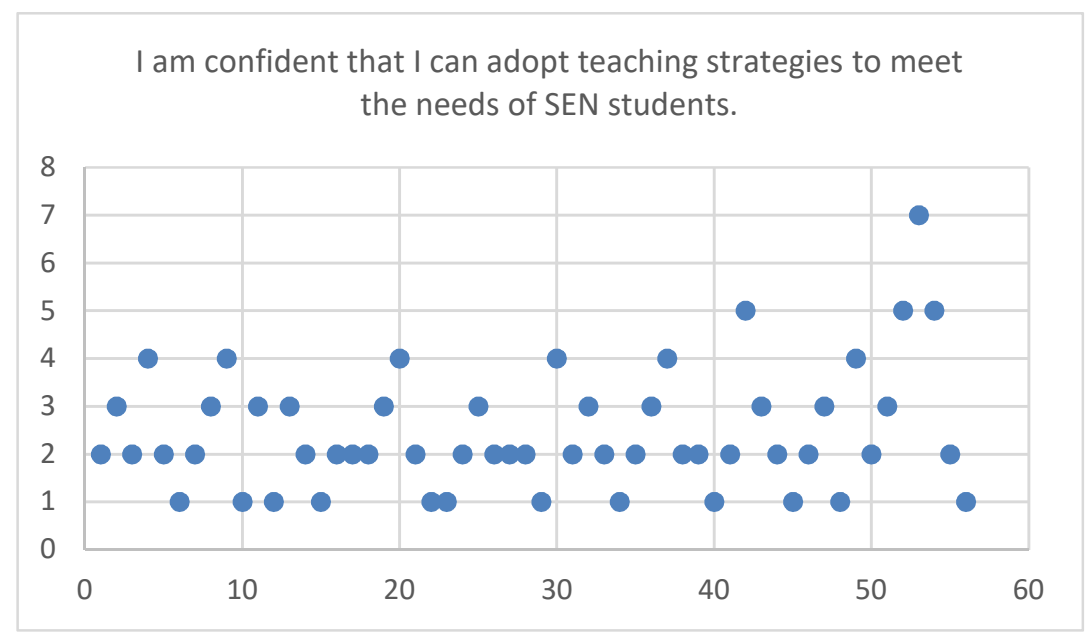

Graph 3: The level of confidence of individual pre-service teachers in adopting teaching strategies to meet the needs of SEN students 
The graph above clearly shows that vast majority of learners indicated they are not confidents how to work with SEN learners. We also present the same data in the form of frequency table. As it can be seen more than one fifth indicated the lowest level; and 6 out of 10 pre-services teachers stated the value 2 (out of ten).

Table 3: Freq. table: I am confident that I can adopt teaching strategies to meet the needs of SEN students

\begin{tabular}{|c|c|c|c|c|}
\hline category & count & $\begin{array}{c}\text { cumulative } \\
\text { count }\end{array}$ & percent & $\begin{array}{c}\text { cumulative } \\
\text { percent }\end{array}$ \\
\hline 1 & 12 & 12 & 21.42857 & 21.4286 \\
\hline 2 & 23 & 35 & 41.07143 & 62.5000 \\
\hline 3 & 11 & 46 & 19.64286 & 82.1429 \\
\hline 4 & 6 & 52 & 10.71429 & 92.8571 \\
\hline 5 & 3 & 55 & 5.35714 & 98.2143 \\
\hline 7 & 1 & 56 & 1.78571 & 100.0000 \\
\hline missing & 0 & 56 & 0.00000 & 100.0000 \\
\hline
\end{tabular}

They are also concerned their workload may increase in case of teaching classes with integrated learners. The average value is 8.6 (minimal value 6 , maximum 10; stand. deviation 1.02).

Compared to the group of teachers, the group of teachers-to-be would like to receive more information about learning difficulties. Especially after returning from teaching practice where they faced the situation of integrated learners into mainstream classes they express central and serious concerns about teaching students with SEN.

A minority of them $(12.5 \%$ - 7 students out of 56$)$ stated they have already had some contact with kids with SEN (excluding the teaching practice). Sharma, Moore and Sonawane observed in 2006 also very low level of contact of pre-service teachers with people with disabilities. In their study "less than $3 \%$ of participants indicated having direct and ongoing contact with a person with a disability" (Sharma, Moore and Sonawane, 2009).

Generally it can be stated that pre-service teachers have a positive attitude to integration, however they are afraid of inclusion. They are not worried that mainstream pupils would be disadvantaged educationally by having students with disabilities in their classes (3.14 positively stated in the questionnaire). Even though they understand that their preparation time will increase significantly if they have students with SEN in their class (8.60), they are also positively accepting the integration and believe that integrated learners in the classroom can enrich all students' learning (6.23). 


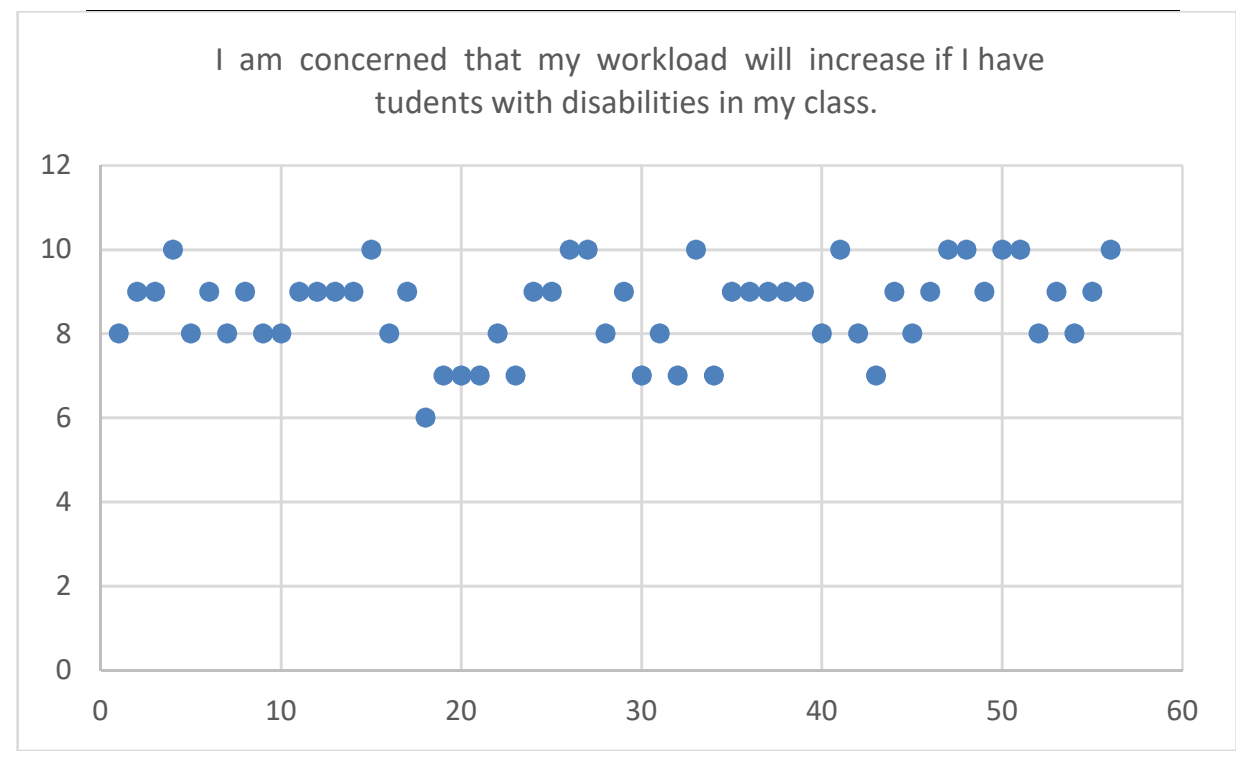

Graph 4: The level of concerns of individual pre-service teachers concerning an increase of workload connected with SEN integration

Table 4: Freq. table: I am concerned that my workload will increase if I have students with disabilities in my class

\begin{tabular}{|c|c|c|c|c|}
\hline Category & count & $\begin{array}{c}\text { cumulative } \\
\text { count }\end{array}$ & percent & $\begin{array}{c}\text { cumulative } \\
\text { percent }\end{array}$ \\
\hline 6 & 1 & 1 & 1.78571 & 1.7857 \\
\hline 7 & 8 & 9 & 14.28571 & 16.0714 \\
\hline 8 & 14 & 23 & 25.00000 & 41.0714 \\
\hline 9 & 22 & 45 & 39.28571 & 80.3571 \\
\hline 10 & 11 & 56 & 19.64286 & 100.0000 \\
\hline Missing & 0 & 56 & 0.00000 & 100.0000 \\
\hline
\end{tabular}

\section{Limitation}

Several limitations are apparent with the presented study. The cohort of inservice teachers consists of elementary school teachers (K1-4) (whose major is not English language and literature) only. Most of those teachers have a course of special pedagogy as a compulsory part of their curriculum. That is, however not truth about teachers who graduated as teachers of so called general-core subjects (or academic subjects) who teach K5-13. 
The pre-service teachers were all English language majors studying at same university what might have influence

\section{Discussion}

Legislation dealing with SEN and students with disabilities was in Slovakia approved more than a decade ago. Schools had to react and create conditions for integration and inclusion. Even though the topic is relatively frequently discussed, the reforms have not been sufficiently reflected in the pre-service preparation. Besides the economy effects (no need further training for in-service teachers immediately after graduation) this will result in better preparation of teachers as well as building their self-confidence that would support the growth of selfactualisation and self-fulfilment. Concerning students' self-confidence one of the ways how to work with students, how to develop their ability of critical selfevaluation might be the use of portfolio (in this case EPOSTL, see more in Straková, 2016, 2016a). Even though in-service teachers sounded quite comfortable (most of them had already participated in certain type of training how to work with learners with disabilities), pre-service English language teachers presented insecurity and uncertainty in teaching integrated learners and they feel they have not enough information on inclusive education. It is essential to include those topics into EFL methodology courses as a compulsory part or supplement. They need, first to understand the benefits and value of integrating learners (and inclusive education), secondly they must understand the strategies, methods and the type of materials that can be used.

\section{Acknowledgement}

This article is a partial outcome of the research project KEGA 065PU-4/2016.

\section{References}

Ahsan, M. T., Sharma, U., \& Deppeler, J. M. (2012). Exploring pre-service teachers' perceived teaching-efficacy, attitudes and concerns about inclusive education in Bangladesh. International Journal of Whole Schooling. 8(2), 1-20. Retrieved from http://files.eric.ed.gov/fulltext/EJ975715.pdf

Anderson, S.L. \& Gumus, S.S. (2006). Preparing pre-service secondary education majors for inclusive classrooms in the USA. International Journal of Inclusive Education, 10 (6), 529-546.

Braunsteiner, M., L. \& Mariano-Lapidus, S. (2014). A Perspective of Inclusion: Challenges for the Future. Global Education Review, 1 (1), 32-43.

Brychtova, L., Hanzelova, E., Repkova K. (2007). ANED country report on equality of educational and training opportunities for young disabled people. In: Report on equality of educational and training opportunities for young disabled people 
- Slovakia. Academic Network of European Disability experts, University of Leeds. Retrieved from http://www.disability-europe.net/theme/education-training CVTI statistics. Retrieved from http://www.cvtisr.sk/cvti-sr-vedeckakniznica/informacie-o-skolstve/statistiky/statisticka-rocenka-

publikacia/statisticka-rocenka-vysoke-skoly.html?page_id=9596

Eddy, E. (2011). On the interconnections among selected aspects of English grammar in Slovak learners' acquisition. Prešovská univerzita v Prešove. Retrieved from http://www.pulib.sk/elpub2/FF/Eddy1/index.html

Forlin, C. (Ed.) (2010). Teacher Education for Inclusion: Changing Paradigms and Innovative Approaches. Abingdon: Routledge

Forlin, C., Earle, C., Loreman, T., \& Sharma, U. (2011). The sentiments, attitudes, and concerns about inclusive education revised (SACIE-R) scale for measuring pre-service teachers' perceptions about inclusion. Exceptionality Education International, 21, 50-65. Retrieved from http://ir.lib.uwo.ca/eei/vol21/iss3/ Hofman, R.H, Kilimo J.S. (2014). Teachers' Attitudes and Self-Efficacy Towards Inclusion of Pupils With Disabilities in Tanzanian Schools. Journal of Education and Training, 1(2), 177-198. doi: http://dx.doi.org/10.5296/jet.v1i2.5760

Jones, C. (2004). Supporting Inclusion in the Early Years. New York: Open University Press. ISBN 0-335-210-910

Jung, W., Cho, G., \& Ambrosetti, D. (2011). Preservice Teachers' Confidence Levels in Working with Students with Special Needs: Improving Preservice Teacher Training Programs. Electronic Journal for Inclusive Education, 2 (7).

Kohútiková, T., Viktorínová, A. (2009). Žiak s VPU na hodinách cudzieho jazyka. Retrieved from http://csppzv.webnode.sk/metodicke-materialy/vyvinoveporuchy-ucenia/ziak-s-vpu-na-hodinach-cudzieho-jazyka/

Loreman, T., Earle, C., Sharma, U., \& Forlin, C. (2007). The development of an instrument for measuring pre-service teachers' sentiments, attitudes, and concerns about inclusive education. International Journal of Special Education, 22, 1-16.

Malak, M. (2013). Inclusive Education in Bangladesh: Are Pre-service Teachers Ready to Accept Students with Special Educational Needs in Regular Classes?. Disability, CBR \& Inclusive Development, 24(1), 56-81. doi:http://dx.doi.org/10.5463/dcid.v24i1.191

Miškolci, J. (2016). Inclusive Education in the Slovak Republic Two Decades after the Dissolution of Czechoslovakia. International Journal of Inclusive Education. 20(2), 199-213.

Nash, T., Norwich, B. (2010). The initial training of teachers to teach children with special educational needs: A national survey of English Post Graduate Certificate of Education programmes. Teaching and Teacher Education. 26 (7), 1471-1480. 
Norwich, B. (2009). Dilemmas of difference and the identification of special educational needs/disability: international perspectives. British Educational Research Journal, 35(3), 447-467.

O'Gorman, E., Drudy, S. (2011). Professional Development for Teachers Working in Special Education/Inclusion in Mainstream Schools: The Views of Teachers and Other Stakeholders. UCD : Dublin.

Oswald M., \& Swart, E. (2011). Addressing South African pre-service teachers' sentiments, attitudes and concerns regarding inclusive education. International Journal of Disability, Development and Education, 58(4), 389-403. doi: 10.1080/1034912X.2011.626665

Pokrivčáková, S. et al. (2015). Teaching Foreign Languages to Learners with Special Educational Needs: e-textbook for foreign language teachers. Nitra: Constantine the Philosopher University.

Rodriguez, C. C., Garro-Gil, N. (2014). Inclusion and Integration on Special Education. Procedia - Social and Behavioral Sciences, 191, 1323-1327. doi:10.1016/j.sbspro.2015.04.488

Ruijs, N.M., \& Peetsma, T. T. (2009). Effects of inclusion on students with and without special educational needs reviewed. Educational Research Review, 4(2), 67-79. doi:10.1016/j.edurev.2009.02.002

Russak, S. (2016). Do inclusion practices for pupils with special educational needs in the English as a foreign language class in Israel reflect inclusion laws and language policy requirements? International Journal of Inclusive Education. doi: 10.1080/13603116.2016.1155666

Sabo, R., Pavlíková, O. (2011). Integrácia - podmienky, východiská, základné procesy. Metodicko-pedagogické centrum v Bratislave : Bratislava

Salend, S. J., Duhaney, L.M.G. (1999). The Impact of Inclusion on Students with and Without Disabilities and Their Educators. Remedial \& Special Education, 20(2), 114.

Savolainen, H., Engelbrecht, P., Nel, M. and Malinen, O. (2012). Understanding teachers' attitudes and self-efficacy in inclusive education: implications for preservice and in-service teacher education. European Journal of Special Needs Education. 27(1), 51-68.

Sepešiová, M. (2013). Rola neurodidaktiky a vyučovanie cudzieho jazyka. In Kačmárová, A. (ed.) English Matters IV (59-67). Prešov: Prešovská univerzita v Prešove. Retrieved from http://www.pulib.sk/web/kniznica/elpub/dokument/Kacmarova4

Sepešiová, M. (2016). Teaching Modes in Higher Education: Lectures \& Seminars. In Straková, Z. (ed.) How to Teach in Higher Education: Selected Chapters. (3059). Prešov: Prešovská univerzita $v$ Prešove, Retrieved from http://www.pulib.sk/web/kniznica/elpub/dokument/Strakova2 
Sharma, U., Shaukat, S. and Furlonger, B. (2015). Attitudes and self-efficacy of preservice teachers towards inclusion in Pakistan. Journal of Research in Special Educational Needs, 15, 97-105. doi: 10.1111/1471-3802.12071

Sharma, U. (2012). Changing Pre-Service Teachers' Beliefs to Teach in Inclusive Classrooms in Victoria, Australia. Australian Journal of Teacher Education, $37(10)$.

Sharma, U., Forlin, C., \& Loreman, T. (2008). Impact of training on pre-service teachers' attitudes and concerns about inclusive education and sentiments about persons with disabilities. Disability \& Society, 23(7), 773-785.

Sharma, U., Moore, D., Sonawane, S. (2009). Attitudes and concerns of pre-service teachers regarding inclusion of students with disabilities into regular schools in Pune. IndiaAsia-Pacific Journal of Teacher Education 37(3), 319-331.

Sparks, R. L. (2009). If you don't know where you're going, you'll wind up somewhere else: The case of foreign language learning disability. Foreign Language Annals, 42(1), 7-26. doi:10.1111/j.1944-9720.2009.01005.x

Srivastava, M., de Boer, A., \& Pijl, S. J. (2015). Inclusive education in developing countries: a closer look at its implementation in the last 10 years. Educational Review, 67(2), 179-195.

Straková, Z. (2016). A Critical Look at the Portfolio as a Tool for Teacher Cognition at Pre-gradual Level: perceptions of students. Jolace, 4(3), 71-85. doi:10.1515/jolace-2016-002

Straková, Z. (2016a). Teaching in the Context of Higher Education. In Straková, Z. (ed.) How to Teach in Higher Education: Selected Chapters. (10-29). Prešov: Prešovská univerzita $v$ Prešove, Retrieved from http://www.pulib.sk/web/kniznica/elpub/dokument/Strakova2

Wing, M.C. (2015) Students with Learning Disabilities in the Foreign Language Learning Environment and the Practice of Exemption. Foreign Language Annals, 48(1), 39-55. American Council on the Teaching of Foreign Languages. doi: $10.1111 /$ flan.12122

Wong-Ratcliff, M., \& Kwok Keung, H. (2011). Can Integrated Education Meet the Needs of Students with SEN? New Horizons in Education, 59(2), 101-115.

\section{Contact}

assoc. prof. Ivana Cimermanová, PhD.

Institute of British and American Studies, Faculty of Arts

University of Presov

17. novembra 1, 08001 Presov, Slovakia

ivana.cimermanova@unipo.sk 